\title{
Shanzheng (善政) and Gongde (公德): Moral Regulation and Narratives of 'Good Government' in Colonial Hong Kong
}

\author{
Cecilia Chu
}

Department of Urban Planning and Design, The University of Hong Kong

Note: The final version of the article has been published in Journal of Historical Geography 42 (October 2013).

http://www.sciencedirect.com/science/article/pii/S0305748813000248

Please cite this article as:

Chu, C. (2013). Shanzheng (善政) and gongde (公德): moral regulation and narratives of 'good government' in colonial Hong Kong. Journal of Historical Geography, 42, 180-192.

\begin{abstract}
While 'good government' has long been hailed as a defining feature of colonial Hong Kong, this paper argues that rather than assuming it as an effect from the adoption of particular British governing principles, it should be seen as an epistemological ordering frame whose existence relied upon constant processes of moralization undertaken by many actors across multiple scales. Central to this moralization was the invocation of certain ways of thinking about the roles of government and citizens that were implicit in Chinese historical experience. These existing moral constructs, transplanted and transformed within the institutional frameworks and emerging cultural milieu on colonial soil, became central elements in the way by which many British officials and Chinese residents came to express themselves, and by doing so constituted themselves as participating, governing subjects upholding colonial rule.
\end{abstract}

To explore how these constructs were deployed in particular situated practices and functioned within broader strategies of colonial governance, this paper focuses on two case studies concerning the improvement of public health amidst growing threats of epidemics between 1900 and 1908. Although these efforts were not successful in containing the spread of diseases, the emphasis on self-help and revival of 'local traditions' for encouraging people to improve their neighborhoods helped engender a sense of pride and solidarity amongst the Chinese residents and propagated the idea that despite under colonial domination, Hong Kong was an orderly, 'civilized' Chinese society that was superior to that of Mainland China itself. Although both case studies were drawn from particular local sites, it is clear that the initiation of the projects, the ways they were implemented and the responses to their outcomes were not confined to their local scales, but were tied to larger shifts in the forms of governance and emerging political discourses beyond Hong Kong. They thus highlight the 'networks of multiple scales' and the translocal processes through which competing conceptions of Hong Kong and its relations to 'the world' were actively being constructed by different actors under colonial rule.

\section{Keywords:}

Colonialism; Governmentality; Scale; Moral regulation; Public health; Corruption; Narratives; Urban space; Hong Kong; China 
For over half a century the Chinese in Hong Kong have enjoyed the fruits of strong, righteous and benevolent government... Under the British flag they have found perfect protection and liberty and from the government they have received equal justice and consideration. (Ho Kai, Chinese member of the Hong Kong Legislative Council, 1897). ${ }^{1}$

It was due to Confucius that the laws governing the relationship of human society, as well as the principles and virtues still exist in China...the mind of the Chinese is still open to improvement; and China [is] still conscious of what is justice. (Lau Chu Pak, president of the Hong Kong Confucian Society, 1911). ${ }^{2}$

Now Hong Kong's six hundred thousand residents live in relative comfort. This is due to good government. I earnestly hope that all of you consider the West and Hong Kong as your models in order that when you return to the motherland, you can help build a good government. (Sun Yat-sen, founder of the Republic of China, address to a group of Chinese students at The University of Hong Kong, 1923). ${ }^{3}$

Speaking to a group of Chinese students at The University of Hong Kong in 1923, Sun Yatsen, the founding father of the Republic of China, praised the British administration for its governing capabilities, particularly for instilling order and civility in this prosperous colony. ${ }^{4}$ Sun credited Hong Kong for nurturing his revolutionary ideas while he was a student there, particularly in relation to the imperative of the rule of law, respect for justice and good government -- all key elements that he believed were necessary for the making of a harmonious, modern society. ${ }^{5}$ While Sun identified these elements in British Hong Kong, he believed they were fully compatible with the traditional Confucian ideal of social order built upon a benevolent government and virtuous citizens. In this regard, Hong Kong was considered a model from which Chinese people could rediscover their own cultural values and develop themselves into self-conscious, responsible citizens capable of building a strong Chinese nation. ${ }^{6}$

Sun's admiration of Hong Kong was somewhat ironic given his tense relationship with the colonial regime, which had previously banished him from the territory for his revolutionary activities that were deemed detrimental to British imperial interests. ${ }^{7}$ But what Sun emphasized in his relation to the territory was a set of moral attributes that were in his eyes universal(izable) and separable from Britain's imperial aggression. Although he had spoken out against the injustice of colonialism in general terms, Hong Kong was undoubtedly to Sun a more well-governed Chinese society than that of Mainland China itself, where the pervasion of corruption at all levels of the government had made the nurturing of 'public spirit' impossible. ${ }^{8}$ His sentiment was shared by many Chinese social reformers with different political views. ${ }^{9}$ Indeed, the idea of Hong Kong as a 'land of justice and civility' has been a recurring theme in descriptions of the territory. ${ }^{10}$ And this extends to contemporary writings 
about the city, which overwhelmingly emphasize the longstanding benefits from the adoption of British policy and legal framework, which were fully embraced by the Hong Kong Chinese and were rightly preserved after the transfer of Hong Kong's sovereignty to China in $1997 .{ }^{11}$

Despite these consistently positive, overarching narratives, it is worth noting that the day-today life in early Hong Kong was rife with tensions. News headlines in the early twentieth century abound with reports of crime of all sorts. Corruption in many government departments was rampant. And although the British lauded their 'laissez-faire' polices for ensuring 'market freedom' for all, they also enacted many forms of discriminatory legislation to protect European privilege. ${ }^{12}$ Yet, the persistence of inequality and social tensions did not, for the most part, incite sustained criticisms against the colonial regime. A common explanation for this 'consent' was that a majority of Chinese in Hong Kong were, like their European counterparts, preoccupied with making as much money as possible before returning to their permanent homelands. Indeed, the colony's transient population provided a key justification for the British to retain authoritarian rule, which was deemed necessary for protecting 'the best interests' of a people with little sense of belonging to this territory. ${ }^{13}$

While the transient character of early Hong Kong might had tempered local political participation, it does not explain the Chinese insistence of Hong Kong as a model of governance and the sense of pride often attached to their narratives. Indeed, a closer look at the opinion pieces circulating in Hong Kong and Canton's popular press in the early twentieth century suggests the existence of a counter discourse which subverted common ascriptions of the Hong Kong people as apathetic subjects indifferent to everything aside from improving their own economic standing. ${ }^{14}$ Rather, as this paper attempts to show, all constituencies imbricated under the colonial system played an active, self-conscious role in the shaping of policy practice and rationality of governance. Although all colonial projects, as Philip Howell points out, were by necessity and by design 'forwarded' by the British Empire to its localities, they were always appropriated or circumscribed to meet emerging demands under specific circumstances. ${ }^{15}$ Attempts to regulate the colonial urban order were certainly of a piece with the values and culture of the British society of the time. Yet the actual construction of this order was never a straightly top down exercise, but was always enabled by 'multiple sources of power and multiple lines of affiliations' that traversed across disparate territories. ${ }^{16}$ It is for this reason that we need to consider the specific histories and geographies of Hong Kong, including especially how subjects of various origins came to act on, resist or reinforce the rules and regulations that were imposed on them by appealing to certain truth claims produced out of these interactions. This is also to suggest the need to pay attention to the interaction between different scales, namely the colonial, the 'local,' the regional, as well as 
multiple imaginaries of an emerging Chinese nation. ${ }^{17}$ As Stephen Legg has succinctly argued, although scales often appear as ahistorical 'frameworks,' they were fought over as techniques of spatial governmentalities and functioned through their impacts on political practice. ${ }^{18}$ The task of the critical scholar thus is to 'reveal the historically specific experiences, effects and affects of scale and the different forms of capital through which they are produced.'

This paper is an attempt to address some aspects of Hong Kong's colonial governmentality ${ }^{19}$ by examining different scalar processes through which British officials and Hong Kong Chinese participated in the construction of a narrative of 'good government,' which came to function as a form of moral regulation and means of political legitimation in the early twentieth century. It should be noted here that although it deals with the concept of 'good government,' the focus is not on the 'moral basis' of the state, but on practices of moralization and how the varied languages of truth produced out of these processes contributed to the formation of a particular kind of 'moral subject.' While good government has long been hailed as a defining feature of colonial Hong Kong, ${ }^{20}$ this paper argues that, rather than assuming it as an effect from the adoption of particular governing principles, it should be seen as an epistemological ordering frame whose existence relied upon constant processes of moralization undertaken by many actors. More specifically, this moralization involved the invocation of certain ways of thinking about the roles of government and citizens that were implicit in Chinese historical experience. These existing moral constructs, transplanted and transformed within the institutional frameworks and emerging cultural milieu on colonial soil, became central elements in the way by which many British officials and Chinese residents came to express themselves, and by doing so constituted themselves as participating, governing subjects buttressing colonial rule.

To explore how these constructs were deployed in particular situated practices and operated as scalar epistemologies within broader strategies of colonial governance over time, I focus on two case studies concerning the improvement of public health amidst growing threats of epidemics between 1900 and 1908. This was an unstable period that saw a surge of antiforeign sentiments instigated by political crisis in Mainland China. ${ }^{21}$ Yet, British governors in Hong Kong generally enjoyed wide popularity amongst the local Chinese. My contention is that this contradiction can only be explained by considering the complex affiliations between the Chinese residents, the colonial regime and authorities in Mainland China, as well as how ongoing reflective comparisons of Hong Kong with its neighboring territories contributed to the construction of a particular discourse of difference. While not refuting that Hong Kong had always been a distinct polity under colonial rule, it is argued here that its 'difference' was achieved not so much by the enactment of policies, but by ongoing scaling practices through 
which certain representations of the territory and their relations with the wider region were reified. $^{22}$

My first case study revisits a plague prevention campaign initiated by Governor Henry Blake (1898-1903), who worked with factions of the Chinese community to mobilize local residents to improve the sanitary condition of a poor disease-ridden neighborhood. Although the campaign was ultimately unsuccessful in deterring the return of epidemics (which continued to ravage the colony until the mid-1920s), the emphasis on self-reliance in overcoming the public health crisis and revival of the traditional Chinese neighborhood system for organizing collective action helped garner a sense of pride and solidarity amongst the residents whilst consolidating the hierarchical structure within the Chinese constituency. It also greatly boosted Blake's standing as a 'benevolent' ruler that fit with Chinese expectation of a 'good official.' Along with other projects, this neighborhood campaign constituted a larger scalar shift of colonial governance that depended less on coercion but self-regulation, where a growing number of 'traditional' philanthropic institutions and neighborhood organizations began to assume the responsibility of monitoring sanitary work in different parts of Hong Kong. Central to this shift was the proliferation of moralizations that linked sanitation with 'public virtues,' and a gradual normalization of particular moral conduct reflecting traditional 'Confucian values' to which all Chinese were assumed to subscribe.

The second case examines the work of a commission appointed by Governor Matthew Nathan (1904-1907) to investigate widespread corruption in the administration of public health legislation. Whilst the investigation itself had little effect in stemming corruption, it strengthened the social position of the 'leading Chinese,' who managed to persuade a substantial number of their countrymen to confess their crimes through a combination of 'moral bullying' and offers of promised benefits. The assumed roles of these Chinese as 'guardians of public goods' and their cozy relations with top-ranked officials not only helped restore some credibility to the colonial regime, but also further promoted the image of Hong Kong as a 'beacon of civilization,' a claim that fed into an emerging political discourse that posited the colony as an appropriate model for social and political reform for Mainland China. Meanwhile, in a different 'scaling out' process, the ongoing challenge in enforcing sanitary regulations revealed by the commission provided new sources for people in other colonial territories, most notably Singapore, to criticize the administrative structures of their own governments that went beyond the legislation of public health.

Although both case studies were relatively unknown episodes drawn from particular local sites, it is clear that the initiation of these projects, the ways they were implemented and the 
responses to their outcomes were not confined to their local scales, but were tied to larger shifts in the forms of governance and emerging political discourses beyond Hong Kong. They thus highlight the 'networks of multiple scales' and the translocal processes through which competing conceptions of Hong Kong and its relations to 'the world' were actively being constructed. ${ }^{23}$ To further consider these connected trajectories, the last section discusses how the Hong Kong model of 'good government' espoused in the popular press in Hong Kong and Canton was increasingly used as a key reference for denouncing the corrupt Qing authority in the years leading up to the Chinese revolution in 1911. The moral imperatives of 'benevolent officials' and 'virtuous citizens' that were repeatedly affirmed in each of these narratives were simultaneously being mapped out in an imaginative geography that linked Hong Kong with its neighboring Chinese province of Guangdong, conjuring a regional representation of 'Cantonese civility' that challenged the longstanding assumptions of Hong Kong's ties with the British empire and Chinese nation.

\section{Private Interests Versus Public Goods: The Regulation of Health and the Protection of}

\section{'Hong Kong's Interests'}

It is not accidental that the narrative of 'good government' in Hong Kong arose amidst growing concern over the threat of epidemics across the British Empire in the nineteenth century. The emerging belief that health and productivity of populations could be optimized by positive environmental settings provided new impetus for urban reforms, most notably in the expansion of urban services and introduction of building standards that would impart new 'sanitary norms. ${ }^{, 24}$ Yet the advent of public health improvement was highly contested affair. As recent research has made clear, the now widely praised Chadwickean sanitary reforms, which involved heavy expenditure and state intervention, were constantly being challenged for their rationality and practicality when first introduced. ${ }^{25}$ Resistance to public health projects was steadfast in the colonies, where gaps in cultural practices and mistrust between native residents and colonial officials incited ongoing tensions and conflicts. ${ }^{26}$ Many improvement schemes were also deterred by vested interests, particularly in places where governments derived significant tax revenue from housing properties, a condition that made officials reluctant to enforce stringent regulatory measures that would cause dissention amongst native landlords. ${ }^{27}$ While the contradictory needs of securing economic vitality and public health posed practical challenges for managing the urban order, they also prompted the production of new claims for justifying these competing agendas. And despite the discrimination they often experienced in the colonial situation, many indigenous people sought to appeal to the logics of colonial capitalism, particularly the need to ensure 'market 
freedom' and limit governmental power as a means to advance their economic interests. ${ }^{28}$ As with other universalist discourses such as those of public health and urban reform, these appeals can be seen as attempts to rescale the colonial hierarchy by envisaging a different kind of urban order in which relations between the colonial state and its subjects would be altered. But to understand the ways in which these contestations unfolded, it is necessary to consider the specific historical contexts that gave shape to existing relations of power.

Often deemed as the most 'laissez-faire' colony amongst Britain's imperial possessions, Hong Kong's economic growth had long relied on Chinese investment, which outnumbered that of British and Europeans by the last quarter of the nineteenth century. ${ }^{29}$ This was particularly the case in housing properties, where the government and property owners were both able to derive large profits thanks to a peculiar land system that severely restricted land supplies and artificially elevated land values. ${ }^{30}$ These property relations significantly influenced the mode of urban development, which was characterized by its lax regulation, exorbitantly high rent and overcrowded conditions. In the wake of widespread epidemic outbreaks elsewhere in the late nineteenth century, the colonial government conducted a series of enquiries into the colony's housing problems and introduced several public health bills aimed at improving sanitary standards in the working class districts. ${ }^{31}$ However, all of these proposals were either turned down by the legislative council or significantly modified to exclude the most stringent measures due to vehement opposition from property owners. ${ }^{32}$ Meanwhile, many initiatives in urban services such as the provision of universal water supplies were hampered by the lack of public funds and corruption associated with their administration. And the same pattern persisted even after the disastrous 1894 bubonic plague outbreak, which killed a large number of Chinese inhabitants in overcrowded tenements. ${ }^{33}$

Notwithstanding the vested interests implicated in the legislative impasse, debates over sanitary reform rarely addressed the systemic nature of the problem, but tended to focus on the 'moral failures' of particular groups to safeguard the 'public good.' Colonial administrators, for example, blamed the delays in health legislation on the "profiteering mentality" of landlords, who were only concerned with maximizing their rental returns with no regards for public welfare. ${ }^{34}$ The British merchants, on the contrary, saw the problem as one of a combination of 'Chinese ignorance' and 'officialdom,' and argued that management of urban affairs would be made more efficient by placing them under a British-controlled municipal council, such as those already established in other colonial territories. ${ }^{35}$ But their request was repeatedly ruled out by the Colonial Office, which alleged the arrangement to be unjust because it would allow a small oligarchy of British taxpayers to rule over a large number of Chinese, who held a majority of property holdings in the colony. ${ }^{36}$ The 
government's fashioning of itself as the guardian of justice and protector of 'Chinese interests' would also become a standard rationale for deferring political reform throughout the colonial period. And this claim was proudly interpreted by some British historians as evidence of the benevolent 'humanitarian liberalism that characterized British colonial policies. ${ }^{37}$

While this kind of rhetoric was, to a degree, self-serving, it is worth noting that colonial administrators had always sought to consciously distinguish their positions from those of the local British and European residents. By proclaiming that it was their duty to defend the 'larger' economic interest and social wellbeing of the 'Hong Kong community,' these officials sought to assume a moral high ground that they believed would give legitimacy to a non-representative, authoritarian government. And the history of Hong Kong seems to suggest they were able to do this with considerable success, not least due to the support from the Chinese, who were generally less critical of the officials, particularly the governors and top-rank administrators, than the local Europeans. ${ }^{38}$ The question that arises here, then, is what enabled the Chinese to arrive at this 'consent,' and in what ways did their views resonate with those of the colonial regime. Certainly this question demands an answer that looks beyond the familiar explanations predicated on the colony's 'transient nature' or the merits of British humanitarianism. I posit that it would be more fruitful to examine how certain political and cultural discourses were invoked and put to use and how people implicated in these processes came to make sense of them. This perspective requires connecting two aspects in the study of governmentality outlined in the introduction of this special issue: the ways in which authorities seek to shape the conduct of subjects, and the multiple ways people came to regulate their actions on their own terms.

In his study of the history of colonial governance in Hong Kong, Steve Tsang attributes the high degree of legitimacy enjoyed by the British administration to the modern civil service system, which was first established in 1862 through the introduction of the 'cadet scheme. ${ }^{39}$ Tsang argues that because many characteristics of the cadets (who typically occupied topranked positions in the colonial administration), such as impartiality, integrity and commitment to public interests, paralleled the Chinese concepts of good governance, they were able to convince the native Chinese of their roles as 'benevolent rulers. ${ }^{40}$ While Tsang usefully points to the confluence of 'moral values' developed in two different contexts, it is worth considering more specifically how these 'values' - or more appropriately 'moral constructs' -- were deployed in particular moralizing narratives through which they came to function as anchors of political legitimacy. As their genesis and evolution makes clear, these constructs were neither timeless nor unanimously endorsed by all. Rather, as the case studies of this paper illustrate, they were actively propagated by Chinese elites and British officials as 
a means to cultivate loyalties and reinforce social hierarchies in Hong Kong's colonial context.

The first of these key constructs was shanzheng (善政), which was a longstanding Confucian moral discourse referring to the policies of a benevolent government. Officials who governed with shanzheng were depicted as just, righteous rulers that concerned themselves with 'the regulation of the livelihood of their subjects. ${ }^{, 41}$ As James Gregor has noted, in Confucian moral philosophy a good ruler regards the assurance of material wellbeing of his subjects a priority because it was the basis for the cultivation of the propriety and good conduct that in turn enabled social peace. And in a peaceful society, every citizen enters into reciprocal obligations with respect to one's immediate family, with one's superiors, and, through them, the state. ${ }^{42}$ To a significant degree, many British governors seemed to have fulfilled the role of benevolent ruler in the eyes of the Hong Kong Chinese, and in this way were able to rise above subordinate officials and establish a level of trust with their colonial subjects, to an extent unsullied by the problems and corruption of day-to-day administration.

Closely related to shanzheng was the idea of gongde (公德), which refers to the virtues of good citizens. Because material wellbeing being was considered to be the basis of the cultivation of proper conduct and morals, those who already possessed wealth and power were expected to display generosity and kindness towards the poor, to lend a helping hand to the disadvantaged and transmit their grievances to higher authorities. ${ }^{43}$ In late imperial China, this role was largely assumed by local gentry-elites who participated in philanthropic activities that also served as a means to enhance their social positions within a highly decentralized administrative structure. ${ }^{44}$ While there were no traditional gentry-elites with official titles in Hong Kong's immigrant society, the British's need to recruit local leaders to help maintain social peace provided a space for Chinese merchants to step in as middlemen. ${ }^{45}$ In time, these merchants came to assume an important role in mediating relations between the colonial administration and the large number of laborers and actively cultivated their image as respectable, virtuous citizens. They also set up philanthropic organizations that offered social services for the community and raised relief funds for natural disasters. These include most notably the Tung Wah Hospital, whose charity work would in time expand to Mainland China and overseas and became a matter of collective pride for the Hong Kong Chinese. ${ }^{46}$ The moral leadership of the elite directors of Tung Wah and other philanthropic associations was also boosted by the personal patronage of the governors and other top-ranked officials, who looked to these institutions as an important bridge between the government and the governed. ${ }^{47}$ 
By associating its governance with the Chinese concept of shanzheng then, the colonial authority was able to make a normative claim on the allegiance of the 'better class Chinese,' who in turn portrayed themselves as the champions of gongde, and in this capacity of the leaders for the Chinese 'everyman' who should support this benevolent exercise of power. The Chinese merchant elites, in committing themselves to channel grievances and improve the livelihood for the average person, allowed the latter to be relieved of having to deal with colonial officials and instead take the cue from their fellow countrymen. While this arrangement strengthened the vertical hierarchy within the Chinese community, it simultaneously created a new sense of solidarity that enabled Chinese of different 'classes' to identify with each other as having shared interests, and by doing so contributed to the construction of difference that readily fed into a racially divided colonial society. At the same time, the emphasis of a generalized 'Chinese moral subject' with a shared Confucian tradition also helped encourage people to participate in their own governance, in turn providing a means of stabilizing the 'benevolent (colonial) state. ${ }^{48}$

It should be emphasized again here that by foregrounding the term 'good government,' the attempt is not to reaffirm the success and achievements of the Hong Kong colonial administration, but to elucidate the dialogic process through which different constituencies participated in colonial governance in accord with their own motivations. What is important, to follow David Scott's discussion of colonial governmentality, is thus not so much about discerning whether native people were included or excluded in particular policies or projects, but to identify the emergence of new 'political games' that both the 'colonizers' and the 'colonized' were obliged to play across multiple terrains if they were to be counted as political. ${ }^{49}$ After all the apparatus of colonial states, as Nicholas Rose contends, had neither the unity nor functionality that were often ascribed to them. ${ }^{50}$ The 'power of the state' was never a given, but always an outcome of the assembling of different actors, ideas and relations of authorities into seemingly durable constructs that came to be largely taken for granted.

Some of these dynamics will be explored in the next section, which examines the roles of British officials and different sections of the Chinese community in an effort to prevent epidemic outbreaks and improve public health. By focusing on a particular intervention in sanitary practices in one small neighborhood in Hong Kong, it provides an example of how the discourse of 'good government' operated with the support of multiple actors implicated in the process, as well as how it constituted a particular scalar dynamic of colonial governance which began to rely increasingly on the self-regulation of colonial subjects. It also illustrates 
how the mutual legitimation of colonial authorities and Chinese elites, while symbiotic, was always being reconfigured in response to emerging demands that were specific in time and place.

\section{Cultivating 'Public Spirits': Henry Blake's Plague Prevention Campaign}

The outbreak of the bubonic plague in 1894 precipitated one of the most severe political and economic crises in Hong Kong's history. As in other cities hit by epidemics at this time, the outbreak led to widespread speculation over the causes of disease and much finger pointing at those held responsible for the catastrophe. ${ }^{51}$ To contain the spread of disease, sanitary authorities imposed militant measures to remove patients from their homes and took over many infected houses, leading to the eviction of thousands of tenants. ${ }^{52}$ These actions spawned widespread anger amongst the Chinese community and demands from landlords for compensation to cover their lost rent. ${ }^{53}$ While many Europeans blamed the Chinese for causing the plague due to their 'insanitary practices,' British merchants stepped up their pressure on the government to relinquish the management of urban affairs to a popularelected municipal council. ${ }^{54}$ By the late $1890 \mathrm{~s}$, the health conditions of the city remained dire. The plague was returning annually and severely hampering the colonial economy. An earlier proposal to systematically rebuild insanitary houses was shelved due to large expenses that would be incurred from compensation to the landlords. ${ }^{55}$ A commission in 1897 reported that many Chinese tenements remained overcrowded and unfit for human habitation, and that the provision of markets, latrines, bathhouses and other amenities essential for public health were insufficient for the need of its rapidly expanding population. ${ }^{56}$

This was the bleak scenario that Henry Blake encountered when he arrived in Hong Kong to begin his governorship in 1898. Adhering to the familiar discourse of 'British justice,' Blake was adamant that management of urban affairs must not be placed in the hand of a selfserving, British-controlled municipal council that was unable to safeguard the long-term interests of Hong Kong. The British merchants nevertheless continued to pursue their cause, and had several times complained to the Colonial Office of the continual failures of the Blake administration to improve the colony's sanitary conditions. ${ }^{57}$ The ensuing bitter exchanges between Blake and the merchants eventually led the Colonial Office to order an external inquiry that ended in the passing of major public health legislation that brought in sweeping new regulation. ${ }^{58}$ However, as will be discussed later on in this paper, their impact was significantly blunted by widespread corruption that debilitated their enforcement. 
It is worth noting, however, that despite the complaints of the merchants, Blake had actually put in much effort to tackle disease prevention throughout his tenure. The lack of attention to his work in many historical accounts could be because he was ultimately unsuccessful in preventing the return of epidemics. ${ }^{59}$ However, a closer look at his initiatives in public health improvement and the responses they generated amongst the wider community can bring to light not only their significance at the time, but also the longer term processes through which particular ideas developed across multiple spatial networks were translated and put to use in local practices, as well as how these projects themselves became sources for reformulating urban policy as part of a larger scalar shift of colonial governmentality.

As evident in archival records, one consistent aspect that defined Blake's approach to colonial governance was the need to adapt British policies to local conditions and cultural practices. ${ }^{60}$ While he was commended by many of his contemporaries for his brilliant governing skills and humanitarian inclinations, his invocation of 'localism' followed existing discourses of cultural relativism and political pragmatism that had long been advocated in British imperial policies. ${ }^{61}$ The rationale behind his improvement schemes in Hong Kong predicated on soliciting Chinese cooperation was also significantly shaped by his earlier governing experience, most notably that in Bahamas, where he had gained renown by improving the sanitation of local villages by training native leaders to help organize the cleaning of wells and drains. ${ }^{62}$ The positive result of his project further convinced Blake that the ultimate success of battling diseases would depend on the extent to which the Chinese taking matters into their own hands. And what was crucial, to use Blake's own words, was 'to put people into the right spirits' so that they would not only comply but actively uphold the regulation of public health. ${ }^{63}$ While this inculcation of conduct clearly follows a central theme in the development of bio-politics in the late nineteenth century onward, its advent depended not only on implementing the 'right' policies, but also the extent to which these policies resonated with local ways of thinking and practices. ${ }^{64}$ As a member of the civil service whose own subjectivity had been shaped by his transnational experience of Empire, Blake sought to translate his successes elsewhere to the context of Hong Kong, and in the process also adapted his own thinking and refined his strategies in dealing with the native Chinese. With this in mind it would be useful, before proceeding to discuss Blake's plague prevention campaign, to first consider some of the ways the Chinese thought about the health crisis and their own moralizations about the problems in relation to the regulations imposed by the colonial administration.

As in other colonies, sanitary reports produced by medical experts in Hong Kong typically emphasized Chinese ignorance of hygiene, which was seen as the main reason they resisted 
regulations that were deemed necessary to improve their health and prevent diseases. ${ }^{65}$ But closer attendance to historical details does not seem to fully support this perspective. As even some officials acknowledged in private correspondence, that the attitudes of the Chinese were in reality more ambivalent. ${ }^{66}$ While cultural divides concerning health practices certainly existed, many poor Chinese tenement dwellers were not against improving their living conditions, particularly the provision of better urban services such as water supplies. ${ }^{67}$ And although landlords generally opposed the application of building codes that would cause a reduction in their rental income, they were supportive of the expansion of public infrastructure and were rightly fearful about the outbreak of epidemics in their own neighborhoods. These somewhat complex attitudes toward sanitary improvement were reflected in many articles in the Chinese newspapers. In contrast to the English press that focused critiques primarily on Chinese ignorance and official arrogance, these writings tended to moralize the issues by entreating officials to soften their highhanded measures on the one hand, and on the other urging the Chinese laboring class, often in paternalistic tones, to cooperate with the colonial authority by reporting plague cases. ${ }^{68}$

Chinese resistance to reporting plague cases had indeed been a significant obstacle to enforcing sanitary regulations. The main reason for this reluctance was that once a household was reported to contain a plague patient, it would be subjected immediately to forced disinfection by the sanitary department. The disinfecting process caused much dissention, not only because it often damaged people's belongings, but also because bribes (called 'squeezes') were regularly demanded by government inspectors and other subordinate workers. ${ }^{69}$ The avoidance of being identified as a plague household had two major consequences. One was the increased dumping of dead patients on the streets at night. ${ }^{70}$ The other was the refusal to participate in rat-catching, an exercise encouraged by the government, which regularly supplied free rat-traps to each house in the Chinese district. ${ }^{71}$ Reports showed that many of these traps were intentionally left sprung, because the finding of an infected rat would result in the same disinfection process that followed the discovery of a plague patient. The government would later try to provide other incentives to capture rats that resulted in some amusing unintended consequences. For example, the offer of a payment of two cents per rat caught immediately resulted in a large number of returns. But subsequently it became apparent that the numbers were swollen by the importation of dead rats from neighboring province of Guangdong for the sake of the reward, fueling a newly flourished transnational trade. The discovery of the trade incited further condemnation from the local British and Europeans of the Chinese's 'profiteering mentality' and lack of moral conscience. ${ }^{72}$ 
In contrary to these accusations, the problems of sanitary regulation were not lost in discussions amongst the Chinese themselves. Newspapers circulating in Hong Kong and Canton had published a handful of thoughtful articles calling people to cooperate with the colonial administration in fighting epidemics. An example was a 1901 leading article appeared in the widely circulated Tsun Wan Yat Po. ${ }^{73}$ Titled 'Reflections on plague prevention and ways to tranquilize the minds of the people,' the article began by explaining in details why Chinese tended to evade particular regulations. 'Chinese people hate trouble,' it contended, 'and their fear of hospitals, of disinfection, of putting lime into their coffins... made them look to government officials as aggressors and enemies... and thus in desperation they fled, lied and even left the dead bodies of their family members in the streets.' The article then asserted, however, that while their resistance was understandable, every Chinese was at heart deeply ashamed of these actions because they violated the age-old tradition of respecting the deceased. The article ended by a polemic appeal to the governor to exercise his shanzheng by lifting the most stringent regulation and punishment for noncompliance. In this way, not only would it be more effective to prevent diseases, but also that 'the living would be pleased and the dead be at rest, and both would be without sorrow and the living would offer endless thanks. ${ }^{, 74}$

Though it is unclear to what extent the editorial policy of the newspaper was directed by those supporting the colonial administration, it nevertheless elucidates a particular paternalistic approach adopted by some of the Chinese towards solving the sanitary problems. Similarly polemical pieces can also be found in the popular press, with many of which assuming a moral high ground that mixed statements urging all Chinese to 'act according to their conscience' and pledging the government to soften the regulatory measures. ${ }^{75}$ It is notable that the colonial governor was always portrayed in these writings as an individual with a moral force that stood above other subordinate officials, and who could, if necessary, act alone to correct their wrongs. And indeed, as mentioned earlier, many Hong Kong governors seem to have made conscious efforts to fit themselves into this assumed benevolent role, which in turn helped to neutralize some of the antagonism between Chinese residents and the colonial officials responsible for day to day administration. Blake's campaign to rally the Chinese to improve the conditions of a plague-ridden neighborhood illustrates a particular working out of the logics of these relationships.

In spring 1903, Blake requested the Sanitary Board to transfer the management of two tenement blocks to him over three months in the summer, a time when the plague was expected to return to the colony. Blake stated that the goal of the campaign was to conduct an experiment to encourage Chinese residents to sanitize their own houses in the absence of 
government officials. If successful, it would provide an object lesson to motivate individuals to help themselves and others and culminate in a sense of enhanced "public spirit" for securing the larger interest of Hong Kong. ${ }^{76}$

The two experimental blocks, which comprised 253 tenement floors with 7,700 tenants, were located at Second and Third Streets of the Western District, a grossly crowded neighborhood with the worst record of epidemics in the city. ${ }^{77}$ Drawing from his earlier work in the Bahamas where he solicited support from local community leaders, Blake began by asking volunteers from the residents to form a kaifong (street committee), to take on the task of supervising the sanitary operation. Although it did not exist previously in this neighborhood, the kaifong was actually a traditional, informal Chinese governing unit that was already present in other parts of Hong Kong. ${ }^{78}$ Members of the kaifong were typically 'civic-minded, status-seeking, and paternalistic citizens' that volunteered themselves to offer service to the community. ${ }^{79}$ While they were not necessarily wealthy, kaifong members were involved in nominating the directors of more prestigious Chinese institutions such as the Tung Wah Hospital, and thus were attached to the existing power structure of the community. Blake's request drew an immediate positive response, with more than a dozen men stepping forward to form the new kaifong to lead the campaign. The project also obtained support from a number of prominent Chinese leaders, including two members of the Sanitary Board, Ho Kai and Fung Wah Chun, as well as Ho Kam Tong, a well known philanthropist who was a director of the Tung Wah Hospital and comprador of the British trading firm Jardine Matheson. ${ }^{80}$ To express his good will, Ho Kam Tong donated a sum of money to the campaign to alleviate the hardship of those who contracted diseases. ${ }^{81}$ Aside from these individuals, Blake also negotiated with several property owners in the neighborhood to have their properties evacuated for use as community washhouses. These spaces would be provided with hot water tanks and residents would organize themselves to systematically bring their clothing and furniture for cleansing. To encourage the voluntary reporting of sickness, Blake promised that houses of plague patients would not need to go through the usual disinfection process. Furthermore, patients would be offered medical service either by European or Chinese doctors, whichever they preferred, in their own homes free of charge. ${ }^{82}$

The plague returned as expected soon after the campaign kicked off in the summer. But although a large number of residents fell victim to disease, the collective cleansing operation went on with rigor. To offer further encouragement to the residents, Blake and the Chinese leaders frequently visited the district together and provided occasions for the local press to promote the project in glowing terms. As the plague began to subside toward the end the summer, Blake proclaimed that his experiment was decidedly a success. Even though 
epidemics continued to ravage the area, not a single dead body was found on the street during the period and residents were willingly reporting sickness not least due to the access of free medical services offered to them. More surprising perhaps was that the landlords who evacuated their properties for use as community washhouses turned down the governor's offer of compensation to cover their lost rent, asserting proudly that there was nothing more meaningful to them than "contributing to the noble cause of plague prevention. ${ }^{, 83}$ Indeed, goodwill from the campaign presented a sharp contrast against the stereotype of Chinese landlords caring nothing but money with no regard whatsoever for public welfare. And this was further played out in a lavish public ceremony at the conclusion of the campaign, where the Chinese leaders and kaifong members took turns to shower praises to each other for their gongde and to thank the governor for his shanzheng, meanwhile vowing they would give their all to combat the plague upon its return in the future.

Although the positive outcome of the campaign owed much to the personal efforts of Blake and the Chinese leaders, it needs to be contextualized within regional networks of authorities beyond Hong Kong. As Alan Baumler notes, popular campaigns initiated from the top had many precedents in late imperial China. ${ }^{84}$ While campaigns were an effective way to accomplish a great deal in a short time, they also had limitations. Campaign successes typically depended on the support of gentry-elites who were accustomed to manage local affairs in a highly decentralized political system. These leaders cultivated loyalty from the poorer class by offering them money and community services. The case in Hong Kong reflected these relationships with a support network system comprised of key local institutions including the kaifong and the more prestigious organizations such as the Tung Wah Hospital that served to enhance the power and benevolent image of the Chinese leaders. Although this kind of network originated from the Mainland, when transplanted to Hong Kong they became key anchors of colonial rule and served to strengthen the mutual dependence between the British administration and Chinese merchant elites. ${ }^{85}$ This sort of patron-client relationship also explains in part why the Chinese often preferred to advance their political and social status through these informal networks rather than by agitating for more fundamental political reforms. In doing so, however, they also reinforced the Confucian discourse of social hierarchy and moral claim upon the populace that being a 'good citizen' (via local structures) entailed following particular kind of 'virtuous' practices.

The revisit of this little-known historical episode provides more general insights into the relationship between the colonial state and the Chinese subjects, which depended on the entrenchment of local institutions in the governing structure. Blake's plague prevention campaign, which was based on the idea of cultural relativism promoted in British imperial 
policies, provided a prime occasion for the Chinese merchants to espouse their moral leadership and legitimize their role as representatives of the community. And even though it was initiated at the top and was led by the elites and kaifong leaders, the campaign helped created to a certain extent a solidarity amongst different groups within the Chinese constituency. The idea that Chinese people could organize themselves to improve their living conditions in lieu of formal official supervision also helped garner a sense of collective pride, as well as contributed to the construction of a generalized 'Chinese moral subject' predicated on self-governance. However, the fact these assertions were made possible only in a colonial territory also created a kind of double irony: The first was the strengthening of conservatism centering on 'Chinese tradition' and rigid social hierarchy in Hong Kong at a time when many intellectuals in China were pushing for radical social reforms. And second, it engendered a sense of sustained superiority amongst the Hong Kong Chinese vis-à-vis their Mainland counterparts. ${ }^{86}$

While this one-off campaign was confined to a small district and did not prevent the plague from returning in the following years, it did lead to a number of lasting changes not only in policies but also more generally in the (self)regulation of day-to-day practices, all of which could be seen as belonging to a larger scalar shift in the rationality of colonial governance. The cleansing operation carried out by the residents themselves was made into a permanent policy in 1904, requiring inhabitants of all tenements throughout Hong Kong to limewash their buildings on a recurring basis. ${ }^{87}$ The Tung Wah Hospital began to assume the task of monitoring the dumping of corpses in the streets and offered monetary rewards for reporting such actions. ${ }^{88}$ Members of the hospital committee and Chinese representatives of the Sanitary Board published regular notices in newspapers urging people to come to them to report any unjust treatment by government officials and abuse of power. Although there were continuous complaints over the sanitary regulations, these efforts seemed to have paid off to a certain extent, both by encouraging the tenement dwellers to come forward to voice their grievances as well as in strengthening their confidence in taking care of their own affairs. At the level of day to day practices, individuals responded positively to these initiatives, and their efforts of monitoring their own behavior also allowed them to identify Hong Kong as an increasingly 'civilized,' orderly city that they participated in making. Both at the time, and in the eyes of many later Hong Kong historians, the term 'good government' continued to work at the level of discourse, shaping narratives of the city and everyday life if not always fully reflecting the actual problems happening on the ground.

Whatever its long-term successes, the campaign also garnered much respect for Governor Blake. This was evident in a petition to the Colonial Office by a large number of Chinese 
pledging for an extension of his governorship in $1903 .{ }^{89}$ Referring to Blake as a 'just, liberal, benevolent and sympathetic character' whose shanzheng had greatly helped improve the livelihood of the people, the petitioners argued that it was all the more important for Blake to continue steering Hong Kong's development in an uncertain period amidst emerging political crisis and rising anti-foreign sentiments in the China region. Although these sorts of praises were not uncommon in Chinese practices in communicating with officials, they posed significant contrasts with some of the accusations against the governor by the local British merchants. These competing truth claims point to the rivaling rationalities deployed by different agents as well as the scaling out processes through which they sought to legitimize their positions by appealing to the larger networks of Empire.

\section{Advocating Justice: The Enquiry into the Administration of the Public Health and Building Ordinance}

At the same time that Governor Blake was being commended for his work in the improvement of sanitation and public health, there was, curiously, a concurrent series of investigations into corruption involving government officials at the Public Works and Sanitary Department. ${ }^{90}$ Capturing the most attention was an enquiry into the administration of a major public health and building legislation enacted at the end of Blake's governorship. The enquiry was ordered by Blake's successor Governor Matthew Nathan three years later after a large number of complaints related to the regulation of the ordinance were reported. ${ }^{91}$ A closer look at the alleged corruption and the responses to the enquiry will shed some light on how these practices were developed and came to function as a specific kind of institution under colonial rule and how the enquiry was itself a means of buttressing the discourse of 'good government.'

The legislation in question was the Public Health and Building Ordinance of $1903 .^{92}$ When first enacted it was hailed as a major legislative achievement that finally ended two decades of struggle to introduce building regulations deemed necessary for improving public health. ${ }^{93}$ As mentioned earlier, many of these regulations, which involved the provision of windows, backyards, and minimum space per person in domestic tenements, had long been resisted by Hong Kong's property owners, who argued that they violated market principles and property rights. The 1903 ordinance was passed after the government agreed to provide compensation for the landlords to cover expenses incurred in the work required by the new regulations. However, this 'grand concession' soon proved to be unworkable due to the many contradictions between different clauses in the ordinance. ${ }^{94}$ And these legal ambiguities, 
coupled with communication gaps between officials of varying ranks in different departments, provided many new opportunities for the abuse of power. ${ }^{95}$

The enquiry was appointed by Nathan in 1906 and was carried out by a special commission consisting of European and Chinese unofficial members. The findings were published in a 300-page report in 1907, confirming that "the administration of the regulations as carried out under the ordinance was most unsatisfactory' and 'irregularities and bribery were rampant within various government departments. ${ }^{96}$ The report alleged that this network of corruption involved both Chinese subordinate workers as well as European inspectors, who allied with outside contractors to establish monopolies in building trades and construction works. These problems were revealed in the testimonies of a large number of property owners, who contended that they were forced to employ particular contractors recommended by government inspectors to carry the building work required by the ordinance. If they did not do so whatever was done would be deliberately destroyed by the inspectors and thus would have to be rebuilt. ${ }^{97}$ The commission reported that these arrangements applied to practically every kind of improvement work ranging from the construction of house drains and windows to the concreting of floors and limewashing of houses, with each linking to a ring of profiteers that encompassed coolies, contractors, foremen, inspectors and other clerks in the Public Works and Sanitary Department.

Henry Lethbridge argues that petty corruption flourished in Hong Kong because the Chinese did not generally see these kinds of practices as 'morally wrong.' To many Chinese who migrated to the colony from the Mainland, petty corruption involving the offering of small payments to officials was largely a normal practice. ${ }^{98}$ Most Chinese in fact did not judge the conduct of an official on whether or not he accepted any 'extra income,' but on his ability to improve the livelihood of the populace and their material wellbeing. This perspective, which corresponded with the Confucian discourse of good government as discussed earlier in this paper, arguably played a role in shaping Chinese expectations of the behaviors of officials in colonial Hong Kong. Indeed, as the commission report acknowledged, because blackmailing was a matter of everyday occurrence in Mainland China, any Chinese who crossed over to the colony tended to accept this as in his own country. This phenomenon was evidenced in the testimonies of the property owners. While many complained about the extortions levied on them by sanitary inspectors, they nevertheless admitted they themselves would be perfectly willing to pay a small sum to subordinate officials to facilitate the granting of building certificates. Meanwhile, the ease in which officials were able to profiteer vis-à-vis the sanitary regulations in turn helped support complex networks within the building trade that involved many contractors, sub-contractors, artisans and laborers that were interrelated with 
each other through kinship and were from the same localities in the Mainland. What one found in Hong Kong then, was an example 'of how a Chinese guild oligopoly system transplanted to colonial soil and accommodated to the apparent exigencies of colonial law by a series of intelligent evasions. ${ }^{99}$

There was, however, one important difference. Unlike in Mainland China where irregular practices permeated officials of all ranks, in colonial Hong Kong they were largely confined to the lower level of the administration. This was because the higher-ranked administrators, including the governors, who were cadets trained in England and set on course for rapid promotion within the civil service, were unlikely to engage in petty corruption that involved small sums of money. ${ }^{100}$ Unlike their lower-ranked European counterparts who were recruited on the spot and were keen to make a better living for themselves, the cadets were conditioned by their training to regard the taking of bribes as immoral behavior. While the Hong Kong Chinese might not have expected 'good officials' to be 'incorruptable,' they were likely impressed by the conduct of the cadets, who gave credibility to the discourse of upholding justice and impartiality that was supposed to be the anchor of British imperial rule. And this also helps explain why the governors were successful, to a considerable degree, in separating themselves as a class above their subordinate officials. And indeed, the very exercise to appoint commissions with non-officials to investigate corruption within the administration presented a salient exception to Chinese practices, thereby contributing to a new conception of justice and a changed 'political game.'

It can be argued that this was the ultimate significance of these enquiries: that they became representations of the benevolent acts of the governor (who appointed the commissions) and provided a means of legitimation for the core members of the colonial administration. And it seems that this was quite effective despite the fact that the commission had done very little to eliminate corruption, which continued to proliferate at the lower levels of the administrative structure. The Chinese response to the work of these commissions can be seen in the newspaper Huazi Ribao, which published an elaborate, fourteen-part article following the release of the commission report in mid $1907 .{ }^{101}$ While the article condemned the 'shameful conduct' of European inspectors involved in corruption, it praised Governor Nathan for his shanzheng, which was epitomized by his decisive move to inquire into the problems out of his personal concern for the livelihood of the people. ${ }^{102}$ This construct of 'governor as protector of the people' was also consciously propagated by the commission members who conducted the investigation. Transcripts of the enquiries showed that witnesses summoned by the commissioners were repeatedly told that "the governor wanted to find out the truth and to 
restore justice for the people... tell us the truth so that we could prosecute those who did wrong and bring matter to justice. ${ }^{, 103}$

While they exalted the governor's benevolence and righteousness, the commission members also sought to associate themselves with him to underscore their own gongde. In particular the two Chinese unofficial members, Fung Wa Chun and Lau Chu Pak, who were both well known philanthropists and directors of the Tung Wah Hospital, made it clear that they were 'the mouthpiece of the governor,' spoke the same language, and were devoted to advocate justice for the people. ${ }^{104}$ In fact, it can be argued that the appointment of a relatively high proportion of Chinese ( 2 out of 6 ) to the commission was itself also a conscious political calculation to present a sense of fairness, not only because the Chinese had by now become the largest property taxpayers in the colony, but also to give acknowledgement that more than two thirds of the witnesses (134 out of 185) summoned by the commission were Chinese. ${ }^{105}$ The position of the Chinese commission members who generally saw themselves as a class 'morally superior' to those of the poorer laborers was made clear in the ways they conversed with the various witnesses. ${ }^{106}$ While they were sympathetic towards the disadvantaged and the poor, vowing to protect them, they also carried a strong paternalistic attitude, making it clear to them that they were the authority vested with power. The transcripts of these conversations also showed that many irregularities were discovered via forceful questioning by the Chinese commissioners, who managed to persuade a number of witnesses to confess their wrongdoings through a combination of what could be termed 'moral bullying' and offers of promised benefits. At the same time, it is important to note that these detailed exchanges also suggest that those witnesses who admitted their crimes did not see themselves being coerced, but arrived at their decisions after weighing the potential consequences of their own actions.

While Chinese merchants sought to shore up their positions as native leaders by showing their allegiance with the governor, those of the less advantaged classes, including coolies, contractors and government clerks, often allied themselves with European inspectors and other subordinate officials who shared with them the desire to make quick money through illicit means. These collaborative activities, in which each party was able to make some gains via different networks under the regulatory system, also helped to neutralize some of the tensions under a highly unequal colonial society. In this way then, the Chinese merchant elite's efforts to position themselves as champions of gongde, and in this capacity as the legitimate leaders for the Chinese populace was a particular move within wider political struggles which included tensions within the Chinese community itself. The invocation of normative language and attempts at the regulation of conduct thus can be seen as a gesture in which the particular behaviors exhorted and marginalized were ultimately less important than 
the alignment of different groups of actors that helped reinforce a hegemonic discourse about Hong Kong.

Finally, it is worth mentioning here that while the work of the commission helped shore up political legitimation for the British administrators and Chinese elites and to an extent deflected criticisms against the actual dysfunctions of the regulatory system, it also provided an occasion for observers elsewhere to compare similar challenges in enforcing sanitary regulation with their own contexts and reflect on what constituted the most appropriate forms of government and roles of citizens. An example can be seen in an editorial published in Singapore's Straits Time in July 1907, less a month after the release of the report on corruption in Hong Kong, and which also corresponded with a major report on the sanitary conditions of Singapore. ${ }^{107}$ By comparing the situations of several colonial cities, including Colombo, Calcutta and Hong Kong, the article urged for restructuring municipal organization in Singapore based on insights gained from these other localities. This example shows just as discourses originating elsewhere were continually being appropriated by local actors within Hong Kong, so were events in Hong Kong radiating outward through different scalar networks.

\section{Localism, Nationalism and the Narrations of 'Civility'}

In hindsight, the irregularities uncovered by the commission should not have surprised anyone familiar with Hong Kong's context because, as the commission report itself acknowledged, these practices had long been well known. Nevertheless, the wide publicity of the report incited new public debates over urban improvement, the protection of property rights and accountability of the government. While the English press used the occasion to condemn 'officialdom' and push for the establishment of a municipal council such as those already established in other British colonies, the Chinese press began to posit Hong Kong as a model of 'good government' of the kind that would help revive the declining Chinese nation. ${ }^{108}$ By way of conclusion, this last section provides some brief reflections on the ways in which Hong Kong was promoted by some Chinese as a 'model' for guiding China's 'national development.' Although these narratives utilized some of the key terms associated with the British 'civilizing mission,' they also articulated them in a language that fit with China's historical and cultural context. Concepts such as 'civility,' 'justice' and 'good government' were invoked as long-existed Chinese attributes. Central to these invocations was a scaling practice through which Hong Kong was posited as a 'Chinese society,' which, with the openness established under foreign rule, had allowed the Chinese to become so 
successful and to manifest their latent potentials as good citizens. While these kinds of claims were invested with nationalistic sentiments that were simmering elsewhere, they were predicated on a localism that distinguished Hong Kong as a distinct territory that was more advanced, modern and civilized. ${ }^{109}$

At the time when the report on corruption captured the attention of the Hong Kong public, the local Chinese press was simultaneously occupied with news of a succession of natural disasters devastating Canton and the Guangdong province. Events in Guangdong had in fact always dominated the content of Chinese newspapers in Hong Kong, with a majority of the population continuing to relate to this part of China as their permanent homeland. And indeed, the close ethnic ties between Hong Kong and Guangdong and the fluid movement of people and capital between the two territories had long contributed to a strong regional identity that somewhat weakened the relation to Hong Kong as a separate colonial polity. ${ }^{110}$ This perspective was reflected in the orientation of the newspapers, where political critiques were mostly directed towards the Chinese authorities in Guangdong and the Mainland rather than the British administration in Hong Kong. And the fact that many Cantonese in this region had prospered through external trade activities under British tutelage had also given them a sense of superiority over ethnic groups in other parts of China. At the same time, the strong connections of the merchant elites to authorities of power in the Mainland also made the former see their destinies as lying not so much in the hands of 'foreigners' but with their own countrymen. These complex ethnic, regional and international affiliations of different scales played significant roles not only in shaping the self-image of the Hong Kong Chinese, but also their participation in the ongoing construction of political discourses pertaining to the new Chinese nation.

As discussed earlier, wealthy Chinese merchants in Hong Kong had from early on engaged in philanthropic activities through which they displayed their gongde and affirmed their claim to moral leadership within the local community. In time, these activities extended beyond the colony to encompass the raising of relief funds for natural disasters and other social services in the Mainland and overseas. ${ }^{111}$ So when the news of a serious flood broke out in Guangdong in the summer of 1908, the Hong Kong philanthropists jumped into action by organizing a series of fund raising events to help the relief efforts. These events, which were heartily supported by the colonial administration, provided a perfect occasion for the Hong Kong Chinese to demonstrate their generosity and benevolence and present Hong Kong as an advanced, wealthy and 'civilized' territory that garnered a great sense of pride amongst the community. 
An example of such exaltations can be seen in the reports of a three-day charity fair held in July 1908. The fair was organized by the colony's most prominent Chinese leaders and were supported by all the European merchants. As reported in the Huazi Ribao, it was by far the most elaborate event of such kind in Hong Kong's history and the first organized solely by Chinese. ${ }^{112}$ The importance of the event was conveyed in the lengthy editorials and commentary pieces devoted to describing minute details of the fair, including the elegant design of its venue, the orderliness of its organization and the generosity of its participants. It also noted the governor's gracious commendation of the Chinese for having organized an event that represented Hong Kong's civility and progress that made it thoroughly comparable to any 'advanced Western nation.'

Throughout 1908 the Huazi Ribao continued to run with contrasting articles. On the one hand were critiques directed toward the Qing government for its indifference to the plight of Guangdong (for it did little to help) and lambasting the corruption and inefficiency of Mainland officials. On the other were writings on the emerging idea of 'Cantonese civility,' along with praise for how the 'generosity and industriousness' of the Cantonese people in Hong Kong and Canton made them become so successful and admirable. For much of the 1900s Hong Kong had been caught up in the unstable atmosphere instigated by political crisis in the Mainland with anti-foreign boycotts that spilled over from Guangdong. And yet throughout this time the British governors enjoyed wide support amongst the local Chinese population. ${ }^{113}$ Indeed, as the quotes from Sun Yat-sen and other Chinese reformers at the beginning of this paper indicate, many revolutionaries seem to perceive Hong Kong as a land of civility and progress despite colonial domination. While many descriptions, such as that exhibited in the charity event, exulted in the colony's orderly nature, it was seen as a result of a smooth combination of British administration and Chinese entrepreneurship. Meanwhile, similar proclamations could be found in the English press, though with the emphasis that these were ultimate proofs of success of the colonial civilizing mission.

Notwithstanding all the claims that associated Hong Kong with modernity and progress, it must be noted that many Chinese in the colony held a relatively conservative view of society. Although some merchants elites supported political reform in China and denounced foreign imperialism, they adhered to the Confucian discourse of social hierarchy and paternalism that helped enhance their prestige and social positions. ${ }^{114}$ On the ground, the Chinese elites were in a relatively cozy relationship with the British officials and European merchants. There were tensions, and yet their close political and economic ties and unfolding prosperity made some go as far as wholeheartedly supporting transforming China under British tutelage. As Tsai has pointed out in his analysis of the social relations in early Hong Kong, the Chinese in 
the colony were not necessarily 'less nationalistic' than their counterparts in the Mainland and likewise wanted to see the emergence of a strong Chinese nation. However, their specific historical experiences made them view the path to get there differently. The gaps between these worldviews, shaped by discrepant economic development of the two territories, became even wider as China underwent further political upheavals and social unrest in the later periods.

This ambivalent attitude towards both the colonial state and the Chinese nation continued to play a key role in shaping the self-image of the Hong Kong Chinese and their relations with each other. As discussed earlier, there was an persistent irony in the history of Hong Kong: that despite it being seen as more prosperous and modern than other territories in Mainland China, the stability of the colony was based in part on a deep conservatism developed under the colonial policy of cultural relativism. The revival of 'local traditions' and emphasis on Chinese cultural values had helped engender a sense of pride and solidarity amongst different classes of people that fed readily into a divided colonial society. The idea that Chinese were able to govern themselves under foreign rule, and that despite all odds they were still able to become successful also strengthened a strong belief in individual upward mobility. In contrast to the 'transient migrant' discourse that saw the Chinese as apathetic subjects, it is argued here that all constituencies played a self-conscious role in the shaping of colonial governance. This view of the Chinese as participating, governing subjects also connected two aspects in the study of governmentality raised in the introduction of this special issue: the ways in which authorities seek to shape the conduct of subjects, and the multiple ways in which people came to regulate their own actions.

Despite the mutual dependence of the Hong Kong administration and the Chinese constituency, it remained a territory with few formal elements of representative government until the end of colonial rule. ${ }^{115}$ While British officials frequently praised the Chinese for their 'public spirit' and philanthropic works, this did not alter the longstanding rhetoric that Hong Kong remained a 'land of transience' and that its people were 'too centered on their self interests' to be given self-rule. The contradictory alignment of interests and discourses, shaped by networks of authorities at different scales, namely the colonial, the 'local' the regional, as well as imaginaries of an emerging Chinese nation, allowed Hong Kong to remain as a distinct territory that was in a sense 'suspended' outside of China, yet continued to affiliate with it and acted as its closest mirror in the eyes of many Chinese on both sides of the border. Central to these relations, as I have tried to illustrate throughout this paper, is a discourse of good government and benevolence linked with the Confucian values of shanzheng and gongde. This discourse was actively promoted by different agents through 
ongoing moralizations taking place at multiple domains, which were at the core of an arrangement that at once bolstered aspects of Chinese power, but simultaneously acted as a powerful frame for the (self)regulation of norms and everyday conduct that helped maintained colonial rule.

\section{Notes}

${ }^{1}$ Ho Kai's address at the celebration of Queen Victoria's diamond jubilee in Hong Kong, reported in Hongkong Daily Press (June 25, 1897).

${ }^{2}$ Lau Chu Pak's address to the Hong Kong Confucian Society reported in Hong Kong Daily Press (October 21, 1911).

${ }^{3}$ Excerpt from Sun Yat-sen's speech at The University of Hong Kong on February 21, 1923, published in Huazi Ribao (February 23, 1923) and Hongkong Daily Press (February 21, 1923).

${ }^{4}$ Huazi Ribao (February 23, 1923) and Hongkong Daily Press (February 21, 1923).

${ }^{5}$ Sun attended the Hong Kong College of Medicine for Chinese in Hong Kong from 1897 to 1892.

${ }^{6}$ A.J. Gregor, Confucianism and the political thought of Sun Yat-sen, Philosophy East and West 31, 1 (1981) 55-70.

${ }^{7}$ Sun was banished from Hong Kong by the colonial government for a five-years period in 1895. Colonial Office (hereafter CO), CO 129/312, Correspondence Between the Hong Kong Government and the Secretary of State for the Colonies, The National Archives, United Kingdom (hereafter TNA), 1902.

${ }^{8}$ In his speech, Sun explained that many grassroot initiatives for improving the conditions of public spaces in China were repeatedly discouraged by the lack of support from local officials, who often demanded extra money to be paid to them in order to approve these projects. See Dr. Sun Yat-sen's address: A neat compliment to Hongkong, Hongkong Daily Press (February 21, 1923).

${ }^{9}$ For a discussion of the tensions between Sun and Hong Kong's Chinese merchants, see J. Tsai, Hong Kong in Chinese History: Community and Social Unrest in the British Colony, 1842-1913, New York, 1993; and S. Chung, Chinese Business Groups in Hong Kong and Political Change in South China, London, 1996.

${ }^{10}$ For example, see reflections of Wang Tao in 1883, quoted in W. Wong, Li Shi De Chen Zhong, Hong Kong, 2000, 225. For a discussion on the Chinese reformers' visions on the modern city, see J. Esherick, Modernity and nation in Chinese City, Esherick (Ed), Remaking the Chinese City, Honolulu, 2000, 1-16. 
${ }^{11}$ For a discussion of these kinds of narratives, see T. Ngo, Colonialism in Hong Kong revisited, in: T. Ngo (Ed), Hong Kong's History, London and New York, 1999, 1-2.

${ }^{12}$ P. Wesley-Smith, Anti-Chinese legislation in Hong Kong, in: M.K. Chan (Ed), Precarious Balance: Hong Kong Between China and Britain, 1842-1992, Hong Kong, 1994, 91-105.

${ }^{13}$ G.B. Endacott, A History of Hong Kong, London, 1958; L. Goodstadt, The rise and fall of social, economic and political reforms in Hong Kong, 1930-1955, Journal of the Hong Kong Branch of the Royal Asiatic Society 44 (2004) 57-81.

${ }^{14}$ Archival research I conducted on this period unearthed a huge range of writings with these kinds of descriptions. These can be seen, for example, in the writers' columns of widely circulated newspapers such as Hauzi Ribao and Tsun Wan Yat Po, as well as many popular magazines and other publications.

${ }^{15}$ P. Howell, Geographies of Empire: Policing Prostitution in Nineteenth-Century Britain and the Empire, Cambridge, 2009, 21.

${ }^{16}$ Howell, Geographies of Empire, 22.

${ }^{17}$ For a discussion on competing narratives of the Chinese nation, see P. Duara, Rescuing Histories from the Nation: Questioning Narratives of Modern China, Chicago, 1995.

${ }^{18}$ S. Legg, Of scale, networks and assemblages: The League of Nations apparatus and the scalar sovereignty of the government of India, Transactions of the British Institute of British Geographers NS 34 (2009), 239.

${ }^{19}$ The notion of governmentality follows that of Foucault as developed by Mitchell Dean, Governmentality: Power and Rule in Modern Society, 1999; and D. Scott, Colonial governmentality, in: J.Z. Inda (Ed), Anthropologies of Modernity: Foucault, Governmentality and Life Politics, London, 2005, 23-49.

${ }^{20}$ S. Tsang, Governing Hong Kong: Administrative Officers from the Nineteenth Century to the Handover to China, 1862-1997, London; New York, 2007.

${ }^{21}$ Tsai, Hong Kong in Chinese History.

${ }^{22}$ For a discussion on morality of scale and representation of the region, see M. Whitehead, From moral space to the morality of scale, Ethics, Place and Environment 6, 3 (2003) 235257.

${ }^{23}$ For a discussion on translocal processes and 'scaling processes,' see Legg, Of scale, networks and assemblages, 234-253; and A. Burton, Not even remotely global: methods and scale in world history, History Workshop Journal 64, 1 (2007) 323-328.

${ }^{24}$ P. Joyce, The Rule of Freedom: Liberalism and the Modern City, London and New York, 2003; T. Osborne, Security and vitality: drains, liberalism and power in the nineteenth century, in: A. Barry et al. (Eds), Foucault and Political Reason: Liberalism, Neo-Liberalism and Rationalities of Government, Chicago, 1996, 99-122. 
${ }^{25}$ For example, see C. Hamlin, Public Health and Social Justice in the Age of Chadwick, Britain, 1800-1854, Cambridge, 1998.

${ }^{26}$ R. Macleod and M. Lewis, Diseases, Medicine, and Empire: Perspectives on Western Medicine and the Experience of European Expansion, London and New York, 1988; B. Yeoh, Contesting Space: Power Relations and the Urban Built Environment, Singapore, 2003.

${ }^{27} \mathrm{C}$. Chu, Between typologies and representation: The tong lau and the discourse of the 'Chinese house,' in: M. Rajagopolan, M. Desai (Eds), Colonial Frames, Nationalist Histories: Imperial Legacies, Architecture, and Modernity, Surrey, 2012, 259-260; Yeoh, Contesting Space,

${ }^{28}$ R. Peckham and D. Pomfret, Introduction, in: Peckham, Pomfret, Medicine, Hygiene, and the Re-ordering of Empire, Hong Kong (forthoming); S. Chattopadhyay, Representing Calcutta: Modernity, Nationalism, and the Colonial Uncanny, New York, 2005.

${ }^{29}$ By 1883, there were 647 Chinese ratepayers against 83 English ratepayers and 98 of other nationalities who were chiefly Portuguese. See Endacott, A History of Hong Kong, 205.

${ }^{30} \mathrm{Chu}$, Between typologies and representation, 259-260.

${ }^{31}$ O. Chadwick, Report on the Sanitary Condition of Hongkong, TNA, 1882.

${ }^{32}$ O. Chadwick and W.J. Simpson, Report on the question of housing of the population of Hongkong, Hong Kong government sessional papers, No.28, 1902, Hong Kong Public Records Office (hereafter HKPRO), 34; E.G. Pryor, Housing in Hong Kong, Oxford, 1983.

${ }^{33}$ For an account of the bubonic plague outbreak in Hong Kong, see M. Echenberg, An unexampled calamity: Hong Kong, 1894, in: Echenberg (Ed), The Global Urban Impact of Bubonic Plagues, 1894-1901, New York and London, 2007, 16-46; M.P. Sutphen, Not what, but where: bubonic plague and the reception of germ theories in Hong Kong and Calcutta, 1894-1897, Journal of the History of Medicine 52 (1997) 81-113.

${ }^{34}$ L. Goodstadt, Uneasy Partners: The Conflict Between Public Interest and Private Profits in Hong Kong, Hong Kong, 34-35.

${ }^{35}$ These included the municipal councils that had already been established in Calcutta, Bombay, Singapore and Shanghai by the end of the nineteenth century.

${ }^{36}$ Endacott, A History of Hong Kong, 1958, 223; K. MacPherson, The city and the state: historical reflection on Hong Kong's identity in transition, 1997 and beyond, Cities 14, 5 (1997) 279-286.

${ }^{37}$ MacPherson, The city and the state, 282.

${ }^{38}$ Tsai, Hong Kong in Chinese History, 290; J.M. Carroll, Edge of Empires: Chinese Elites and British Colonials in Hong Kong, Cambridge, 2005, 188-190. 
${ }^{39}$ Tsang, Governing Hong Kong: Administrative Officers from the Nineteenth Century to the Handover to China, 1862-1997, London; New York, 2007; H. Lethbridge, Hong Kong cadets, 1862-1941, Journal of the Hong Kong Branch of the Royal Asiatic Society 10 (1970) 36-56.

${ }^{40}$ Tsang, Governing Hong Kong, 27-28.

${ }^{41}$ See the interpretation of the Confucian concept of 'good government' in Gregor, Confucianism and the political thought of Sun Yat-sen, 59. While Gregor has not explicitly addressed the term shanzheng in his article, this is a key term in many Chinese writings that assessed government policies throughout Hong Kong's colonial rule.

${ }^{42}$ Gregor, Confucianism and the political thought of Sun Yat-sen, 59. For a critical discussion on the influence of Confucian thought on Chinese society, see J.B. Tamney and L.H. Chiang (Eds), Modernization, Globalization, and Confucianism in Chinese Societies, Westport, 2002. ${ }^{43}$ Gregor, Confucianism and the political thought of Sun Yat-sen, 59-60.

${ }^{44}$ P.M. Thornton, Disciplining the State: Virtue, Violence, and State-making in Modern China, Cambridge, 2007, 224-25; F.E. Wakeman, Civil society in late imperial and modern China, in: L.H. Wakeman (Ed), Telling Chinese History: A Selection of Essays, Berkeley, Los Angeles and London, 2009, 343-353; Tsai, Hong Kong in Chinese History, 10.

${ }^{45}$ Tsai, Hong Kong in Chinese History, 10, 70-77; Carroll, Edge of Empires, 59-83.

${ }^{46}$ E. Sinn, Power and Charity: A Chinese Merchant Elite in Colonial Hong Kong, Hong

Kong, 2003, 82-120; H. Lethbridge, Hong Kong, Stability and Change, Hong Kong and New York, 1970, 52-65; and Tsai, Hong Kong in Chinese History, 70-77.

${ }^{47}$ The other prominent institutions include the Po Leung Kuk, a sister organization of Tung Wah Hospital that offered social services to kidnapped women and children, and the District Watch Committee.

${ }^{48}$ A. Hunt, Governing Morals: A Social History of Moral Regulation, Cambridge, 1999, 1618.

${ }^{49}$ Scott, Colonial governmentality, 28.

${ }^{50}$ N. Rose, Governing 'advanced' liberal democracies, in: A. Barry et al, Foucault and Political Reason: Liberalism, Neo-liberalism and Rationalities of Government, Chicago, 1996, 42.

${ }^{51}$ For examples of similar cases elsewhere, see P. Kidambi's chapter, Disease of locality: Plague and the crisis of 'sanitary order,' in The Making of an Indian Metropolis: Colonial Governance and Public Culture in Bombay, 1890-1920, Ashgate, 2007, 49-70; and various chapters in Echenberg, The Global Urban Impact of Bubonic Plagues.

${ }^{52}$ Sutphen, Not what, but where, 87-113.

${ }^{53}$ CO 129/263/10928, Sanitary improvement of Taipingshan, 1894.

${ }^{54} \mathrm{~K}$. McPherson, The city and the state, 282. 
${ }^{55}$ Report of the Insanitary Properties Commission, HKPRO, 1898.

${ }^{56}$ Report of the Insanitary Properties Commission, HKPRO, 1898.

${ }^{57}$ CO129/309/29155, June 7, 1901; CO129/305/29164, Sanitary Condition of the Colony, July 1901.

${ }^{58}$ Public Health and Building Ordinance, Oridinance no.1, Hong Kong, 1903.

${ }^{59}$ The bubonic plague continued to return to Hong Kong on a regular basis until the mid 1920s.

${ }^{60}$ CO 129/304/9277, Disease in the colony, 1901.

${ }^{61}$ P. Howell and D. Lambert, Sir John Pope Hennessy and colonial government: humanitarianism and the translation of slavery in the imperial network, in D. Lambert, A. Lester (Eds), Colonial Lives Across the British Empire: Imperial Careering in the Long Nineteenth Century, 2006.

${ }^{62}$ Sir Henry Blake and the prevention of plague, Hongkong Telegraph (August 28, 1903); Prevention of plague, Hongkong Daily Press (August 4, 1903).

${ }^{63} \mathrm{CO} 129 / 318 / 35303$, Treatment of plague patients in their own home and in local hospitals, 1903.

${ }^{64}$ See related discussion on India by E.F. Irschick, Conversations in Tarangambadi: Caring for the self in early eighteenth century South India, Comparative Studies of South Asia, Africa and the Middle East 23, 1-2 (2003) 3-20.

${ }^{65}$ This can be seen in numerous reports on Hong Kong's sanitary conditions prepared by P.B.C. Ayres, colonial surgeon in Hong Kong from 1873 to 1896.

${ }^{66}$ CO 129/304/9277, Disease in the colony, 1901.

${ }^{67}$ CO 992/4, Report on the Sanitary Conditions of Hongkong, 1882, 66-78.

${ }^{68}$ These articles can be found, for example, in some of Hong Kong's most widely circulated newspapers, such as Huazi Ribao (The Chinese Mail), Tsun Wan Yat Po, (Universal Circulating Herald), and Chung Kuo Pao.

${ }^{69}$ CO 129/318/35303, Treatment of plague patients in their own home, 1903.

${ }^{70}$ Ordinance no. 15, Hong Kong, 1894.

${ }^{71}$ CO 129/318/35303, Treatment of plague patients in their own home, 1903; CO

129/297/10315, Plague: destruction of rats, 1900.

${ }^{72}$ CO 129/297/10315, Plague: destruction of rats, 1900.

${ }^{73}$ Tsun Wan Yat Po (June 20, 1901).

${ }^{74}$ Tsun Wan Yat Po (June 20, 1901).

${ }^{75}$ There was even an essay competition organized by Huazi Ribao calling for suggestions for the best means of plague prevention. Titled 'The Protection of Life in Hongkong,' the competition was noted by Blake, who seemed to have been influenced by the Chinese 
approach to the problem in some of his subsequent policy decisions. This included his effort to exempt Hong Kong from complying with the Venice Convention of plague prevention, which ruled that all plague patients must be removed from their homes once sickness was discovered. CO 129/305/617, 1901.

${ }^{76}$ Prevention of plague, Hongkong Daily Press (August 4, 1903).

${ }^{77}$ CO 129/318/35303, Treatment of plague patients in their own home, 1903.

${ }^{78}$ Lethbridge, Hong Kong, Stability and Change, 58-59; Sinn, Power and Charity, 16-17, A.K. Wong, Chinese voluntary associations in Southeast Asian cities and the kaifongs in Hong Kong, JHKBRAS 11 (1971) 62-73.

${ }^{79}$ Lethbridge, 59. The kaifong in Hong Kong also participated in the nomination of directors of the more prestigious Chinese institutions, including the Tung Wah Hospital, Po Leung Kuk and the District Watch Committee.

${ }^{80}$ F. McDonald, Ho Kom-tong: A Man for All Seasons, Hong Kong, 2003.

${ }^{81}$ Prevention of plague: the experimental block, Hongkong Daily Press (August 4, 1903); Sir Henry Blake and the prevention of plague, Hongkong Telegraph (August 28, 1903).

${ }^{82}$ Hongkong Daily Press (August 4, 1903); Hongkong Telegraph (August 28, 1903).

${ }^{83}$ Hongkong Daily Press (August 4, 1903); Hongkong Telegraph (August 28, 1903).

${ }^{84}$ A. Baumler, The Chinese and Opium Under the Republic, New York, 2007, 19-20.

${ }^{85}$ Tsai, Hong Kong in Chinese History, 75-77.

${ }^{86}$ Carroll, Edge of Empires, 190-194.

${ }^{87}$ Ordinance no.5, Hong Kong, 1904. From this time on residents were required to limewash their buildings twice a year.

${ }^{88}$ For example, these notices were regularly posted in the Huazi Ribao and Tsun Wan Yat Po.

${ }^{89}$ CO 129/316/16512, Petition from Chinese inhabitants, 1903.

${ }^{90}$ Enquiries into operation of the administration had many precedents. But the ones conducted from the 1900s onward seem to have generated more attention in the press. One example was an investigation into the operation of the Public Works Department after a disastrous house collapse killed a large number of people in 1901. See Report of the Commission to Enquire into the Public Works Department, HKPRO, 1902.

${ }^{91}$ Report of the Commission to Inquire into the Working of the Public Health and Building Ordinance and the Existence of Corruption in the Sanitary Department, HKPRO, 1907.

${ }^{92}$ Ordinance no.1, Hong Kong, 1903.

${ }^{93}$ Chadwick, Preliminary Report of the Sanitation in Hong Kong, no.17 of 1902, HKPRO, 1902; Pryor, Housing in Hong Kong, 8-19; E. Ng, Regulate for light, air and healthy living, HKIA Journal 34, 1 (2004) 14-17. 
${ }^{94}$ Chadwick, Preliminary Report of the Sanitation in Hong Kong. For example, there was much confusion in the requirements applied to houses built before and after the passing of the ordinance, resulting in uneven charges.

${ }^{95}$ Chadwick, Preliminary Report of the Sanitation in Hong Kong. Also see the discussion in Lethbridge's chapter on bureaucratic corruption in Hong Kong: Stability and Change, 214237.

${ }^{96}$ Report of the Commission to Inquire into the Working of the Public Health and Building Ordinance and the Existence of Corruption in the Sanitary Department, HKPRO, 1907, 185(5-6).

${ }^{97}$ Report of the Commission to Inquire into the Working of the Public Health and Building Ordinance and the Existence of Corruption in the Sanitary Department, 185(16).

${ }^{98}$ Lethbridge, Hong Kong: Stability and Change, 221-222.

${ }^{99}$ Lethbridge, Hong Kong: Stability and Change, 229.

${ }^{100}$ The problem of corruption did spread to the higher level of the Government in the postwar period when Hong Kong underwent rapid industrialization and vastly expanded the scale of its economy. Lethbridge explains that the situation allowed the emergence of "black-market bureaucracy," referring to "a stage in which a bureaucracy ceases to be patterned after the mandatory pricing model and takes on the characteristic of the free market." See Lethbridge, Hard Graft in Hong Kong: Scandal, Corruption, the ICAC, Hong Kong and New York, 1985. For details on the cadets scheme, see Tsang, Governing Hong Kong.

${ }^{101}$ Huazi Ribao (May 17 to June 6, 1907).

${ }^{102}$ This comment was first made at the time in the Huazi Ribao when the commission was appointed by Nathan in 1906. Huazi Ribao (April 15, 1906).

${ }^{103}$ Report of the Commission to Inquire into the Working of the Public Health and Building Ordinance, HKPRO, 1907.

${ }^{104}$ The two Chinese unofficial members were Fung Wa Chun, who was a member of the Sanitary Board, and Lau Chu Pak, who later became a member of the Hong Kong Legislative Council.

${ }^{105}$ Out of the 185 witnesses, 134 were Chinese. While a majority of them were contractors and small property owners, they also included a number of wealthy merchants and landlords who were themselves closely associated with the members of the Commission.

${ }^{106}$ See Carroll's discussion on "better class Chinese" in Edge of Empires, 37-57; and Sinn, Power and Charity, 82-120.

${ }^{107}$ The Straits Time (July 4, 1907, 6.)

${ }^{108}$ For an example of the criticism made in the English press, see editorials in the Hongkong Daily Press (May 17, 18, 21, 1907). 
${ }^{109}$ For a general discussion on methodological issues related to the study of the 'local', 'regional' and the 'global,' in Chinese history, see P. Duara, The Global and Regional in China's Nation-Formation, London and New York, 2009, 1-39.

${ }^{110}$ See Tsai's analysis of the social unrests in early Hong Kong and the relationship between Hong Kong and Canton, in Tsai, Hong Kong in Chinese History.

${ }^{111}$ Sinn, Power and Charity, 98-101.

${ }^{112}$ Hauzi Ribao (July 11-18, 1908).

${ }^{113}$ The most notable was the anti-American boycott in 1905 and anti-Japanese boycott in 1907. See Tsai, Hong Kong in Chinese History, 182-237.

114 Tsai, 75-77; W. Law, Collaborative Colonial Power: The Making of the Hong Kong Chinese, Hong Kong, 2009, 9-27.

${ }^{115}$ L. Goodstadt, Uneasy Partners: The Conflict between Public Interest and Private Profit in Hong Kong, Hong Kong, 2005. 